\title{
Isolation, Characterization and Screening of Sulphur Oxidizing Bacteria from Rhizosphere Soils of Groundnut
}

\author{
A. Narendra Reddy*, A. Vijaya Gopal, R. Lakshmipathy and V. Padma \\ Departtment of Agricultural Microbiology, Advanced Post Graduate Centre, \\ Lam, Guntur, India \\ *Corresponding author
}

\begin{abstract}
A B S T R A C T
Keywords

Sulphur oxidizing bacteria, Sulphate production

Article Info

Accepted:

15 July 2018

Available Online:

10 August 2018

This study was conducted to isolate sulphur oxidising bacteria from saline soils of groundnut growing places in Andhra Pradesh, India and they were characterized based upon their morphological and biochemical characteristics. Among 10 isolates five were capable of reducing the $\mathrm{pH}$ of the growth media below 5.0 from initial $\mathrm{pH} 8.0$ and made the highest sulphate production in the growth media and sulphate production of isolates ranges from $1.264 \mathrm{mM}$ to $0.390 \mathrm{mM}$.
\end{abstract}

\section{Introduction}

Sulphur Oxidizing bacteria (SOB) are the group of bacteria which play an important role in the biogeochemical cycle of sulphur compounds in the environment. Members of this group include free living rods or ovoids of the genera Thiobacillus, Thiomonas, Acidiphilium and Thiomicrospiraas well as the morphologically conspicuous gliding and nongliding filamentous forms of the genera Beggiatoa and Thiothrix (Wirsen et al., 2002).

Sulphur is one of the major plant nutrients after $\mathrm{N}, \mathrm{P}$, and $\mathrm{K}$ especially in pulses and oilseed crops as a constituent of essential amino acids cystine, cysteine and methionine. Sulphur Oxidizing Bacteria (SOB) enhance the oxidation of ' $S$ ' and speed up the production of sulphates and make it available to plants. In the present study attempt was made to isolate SOB from rhizosphere soils of groundnut which are saline in nature.

\section{Materials and Methods}

\section{Sample collection}

Isolation of Sulphur Oxidizing Bacteria was done by using rhizosphere soil samples collected from various groundnut growing places of Andhra Pradesh, India. 
Culture media, growth conditions, and maintenance

The culture media used for isolation of sulphur oxidizing bacteria include modified thiosulphate broth (Parker, 1957) contained $5.0 \mathrm{~g} \mathrm{Na}_{2} \mathrm{~S}_{2} \mathrm{O}_{3}, 0.1 \mathrm{~g} \mathrm{~K}_{2} \mathrm{HPO}_{4}, 0.2 \mathrm{~g} \mathrm{NaHCO}_{3}$, $0.1 \mathrm{~g} \mathrm{NH}_{4} \mathrm{Cl}$, 5.0g Glucose in $1000 \mathrm{ml}$ of distilled water, with $\mathrm{pH}$ 8.0. Bromocresol purple was the indicator used (Vidyalakshmi and Sridar, 2006). Five grams of sample was added to $50 \mathrm{ml}$ of broth dispensed in conical flasks under aseptic conditions. The flasks were incubated at room temperature for three weeks.

The isolates obtained were purified by transferring to fresh broth twice at fortnightly intervals. The isolates were then streaked on thiosulphate agar medium and individual colonies were obtained. The single colonies were picked and preserved on thiosulphate slants. The pure cultures were labelled and used for characterization and further studies.

\section{The $\mathrm{pH}$ reduction test}

The pure cultures were inoculated on the growth media with initial $\mathrm{pH}$ adjusted to 8.0 and incubated at room temperature for 7 days. The final $\mathrm{pH}$ of the growth media was measured using $\mathrm{pH}$ meter. The isolates were screened for their efficacy to reduce the $\mathrm{pH}$ from 8.0 to 5.0 or less than 5.0. The selected isolates were further studied for their morphological and biochemical characterization.

\section{Morphological characterization}

Obtained isolates were plated over thiosulphate agar media with $\mathrm{pH} 8.0$ to study the colony morphology. Single colony was picked and prepared slide for studying cell morphology (Bergey and Boone, 2009), Gram staining and shape.

\section{Biochemical characterization}

Indole test, starch hydrolysis, citrate utilization, phosphate solubilization and sulphate production were done to study the biochemical characters of the isolates.

Starch Hydrolysis: Sterile starch agar plates were spotted with $10 \mu \mathrm{l}$ overnight broth cultures of the isolates and incubated at $28 \pm 2^{\circ}$ $\mathrm{C}$ for 48-72 h. After incubation, the plates were flooded with iodine solution. The formation of a transparent zone around the colony was taken as positive reaction for the test.

Indole production: Sterilized SIM agar slants were inoculated with the overnight cultures of the isolates and incubated for $72 \mathrm{~h}$ at $28 \pm 2^{\circ} \mathrm{C}$. Following incubation, 10 drops of Kovac's indole reagent were added to each tube. The isolates showing production of red colour were recorded as positive for indole production.

Gelatin liquefaction: The overnight cultures of the test isolates were inoculated to sterilized nutrient gelatin tubes and incubated for $48 \mathrm{~h}$ at $28 \pm 2^{\circ} \mathrm{C}$. Then the tubes were kept in the refrigerator for 30 minutes at $4^{\circ} \mathrm{C}$. The isolates showing liquefied gelatin were taken as positive and those which resulted in solidification of gelatin on refrigeration were recorded as negative.

Citrate utilization: Isolates were streaked on Simmon's citrate agar slants and incubated at $28 \pm 2^{0} \mathrm{C}$ for $24 \mathrm{~h}$. Change in colour from green to blue indicates the positive reaction for citrate utilization.

Catalase test: This test was performed to study the presence of catalase enzyme in bacterial colonies. Fresh cultures of Pure isolates were taken on glass slides and one drop of $\mathrm{H}_{2} \mathrm{O}_{2}(30 \%)$ was added. Appearance 
of gas bubble indicated the presence of catalase enzyme.

Sulphate estimation: The isolates were further screened on the basis of production of sulphate ion $\left(\mathrm{SO}_{4}^{-2}\right)$ The amount of sulphate ions $\left(\mathrm{SO}_{4}^{-2}\right)$ produced during growth of sulphur-oxidizing bacteria on Thiosulphate broth medium was determined spectrophotometrically. A loopful of $48 \mathrm{hrs}$ old culture of each isolate was inoculated into $10 \mathrm{ml}$ of Thiosulphate broth. All the inoculated tubes were incubated at $30^{\circ} \mathrm{C}$ for 7 days. After 7 days of incubation, the broths were centrifuged at $15000 \mathrm{rpm}$ for 10 minutes to separate the supernatant from the cell growth. Sulphate production was measured by adding 1:1 barium chloride solution (10\%, w/v) with bacterial culture supernatant followed by mixing the suspensions vigorously (Cha et al., 1999). A resulting white turbidity due to barium sulphate formation was measured at $450 \mathrm{~nm}$. The values obtained were compared with the sulphate standard curve.

\section{Results and Discussion}

Isolation and screening of isolates: A total of 10 isolates were obtained from rhizosphere soils of groundnut based upon the $\mathrm{pH}$ reduction test (Fig. 1). They were named asBSS2, AKS2, NNS1, VKS3, NJS2, NDS1, NGS2, NUS2, KKS1 and KAS1. Among the 10 isolates, AKS2, NNS1, NUS2, NGS2 and NJS2 reduced the $\mathrm{pH}$ of thiosulphate broth to 5.0, 4.5 and 4.0 respectively afterseven days of incubation. VKS3, NDS1, BSS2 and KKS1 reduced the $\mathrm{pH}$ to $5.5,6.0$ and 6.5 on thiosulphate broth respectively after 7 days. A control for was maintained with $\mathrm{pH}$ 8.0. The results are shown in Table. 1.

Characterization of isolates: Morphological and Biochemical characterization of all the isolates were done. Colony appearance ranges from milky white to dull white in colour and margin is regular to irregular in nature; colony surface of most of the isolates was raised and flattened. Cells were Rod shaped. All the isolates were Gram negative in nature. The characters of isolates were presented in Table 2. Ten isolates were obtained from rhizosphere soil samples of groundnut. In earlier studies various researchers isolated Sulphur oxidizing bacteria isolates from diverse habitats, including mangroves soils, acid mines drainage, paddy rhizosphere, treated tannery effluent, untreated tannery effluent, rhizosphere soil, acidic soil and treated beverage waste.

Table.1 $\mathrm{pH}$ reduction in growth media by sulphur oxidizing bacteria

\begin{tabular}{|c|c|c|}
\hline $\begin{array}{c}\text { Name of the } \\
\text { SOB isolate }\end{array}$ & $\begin{array}{c}\text { Initial pH of the } \\
\text { growth media }\end{array}$ & $\begin{array}{c}\text { Reduction of pH in growth } \\
\text { media of Thiosulphate broth }\end{array}$ \\
\hline BSS2 & 8.0 & 6.5 \\
\hline AKS2 & 8.0 & 5.0 \\
\hline NNS1 & 8.0 & 5.0 \\
\hline VKS3 & 8.0 & 5.5 \\
\hline NJS2 & 8.0 & 4.0 \\
\hline NDS1 & 8.0 & 6.0 \\
\hline NGS2 & 8.0 & 4.5 \\
\hline NUS2 & 8.0 & 5.0 \\
\hline KKS1 & 8.0 & 6.5 \\
\hline KAS1 & 8.0 & 7.0 \\
\hline
\end{tabular}


Table.2 Morphological and biochemical characteristics of SOB isolates

\begin{tabular}{|c|c|c|c|c|c|c|c|c|c|c|c|}
\hline \multirow{2}{*}{\multicolumn{2}{|c|}{ Characters }} & \multicolumn{10}{|c|}{ Isolates } \\
\hline & & BSS2 & AKS2 & NNS1 & VKS3 & NJS2 & NDS1 & NGS2 & NUS2 & KKS1 & KAS1 \\
\hline \multicolumn{2}{|c|}{ Morphology } & $\begin{array}{c}\text { Rod } \\
\text { shape }\end{array}$ & $\begin{array}{c}\text { Rod } \\
\text { shape }\end{array}$ & $\begin{array}{c}\text { Rod } \\
\text { shape }\end{array}$ & $\begin{array}{c}\text { Rod } \\
\text { shape }\end{array}$ & $\begin{array}{l}\text { Rod } \\
\text { shape }\end{array}$ & Rod shape & $\begin{array}{c}\text { Rod } \\
\text { shape }\end{array}$ & $\begin{array}{c}\text { Rod } \\
\text { shape }\end{array}$ & $\begin{array}{c}\text { Rod } \\
\text { shape }\end{array}$ & $\begin{array}{c}\text { Rod } \\
\text { shape }\end{array}$ \\
\hline \multicolumn{2}{|c|}{ Gram reaction } & -ve & - ve & -ve & -ve & -ve & -ve & -ve & -ve & -ve & - ve \\
\hline \multicolumn{2}{|l|}{$\begin{array}{l}\text { Colony } \\
\text { characters }\end{array}$} & $\begin{array}{l}\text { Smooth, } \\
\text { Regular }\end{array}$ & $\begin{array}{l}\text { Smooth, } \\
\text { Regular }\end{array}$ & $\begin{array}{l}\text { Smooth, } \\
\text { Regular }\end{array}$ & $\begin{array}{l}\text { Smooth, } \\
\text { Regular }\end{array}$ & $\begin{array}{l}\text { Mucoid, } \\
\text { Regular }\end{array}$ & Smooth, Irregular & $\begin{array}{l}\text { Smooth, } \\
\text { Regular }\end{array}$ & $\begin{array}{l}\text { Slimy, } \\
\text { Regular }\end{array}$ & $\begin{array}{l}\text { Smooth, } \\
\text { Irregular }\end{array}$ & $\begin{array}{l}\text { Smooth, } \\
\text { Irregular }\end{array}$ \\
\hline \multirow{3}{*}{$\begin{array}{l}\text { Optimum } \\
\mathrm{pH}\end{array}$} & 4 & + & + & + & + & + & + & + & + & + & + \\
\hline & 7 & + & + & + & + & + & + & + & + & + & + \\
\hline & 9 & + & + & + & + & + & + & + & + & + & + \\
\hline \multicolumn{2}{|c|}{$\begin{array}{l}\text { Indole } \\
\text { production }\end{array}$} & - & + & + & + & + & - & - & - & + & + \\
\hline \multicolumn{2}{|l|}{$\begin{array}{l}\text { Citrate } \\
\text { utilization }\end{array}$} & + & + & + & - & + & + & - & - & - & + \\
\hline \multicolumn{2}{|c|}{$\begin{array}{l}\text { Gelatin } \\
\text { liquefaction }\end{array}$} & - & - & - & - & - & - & - & - & - & - \\
\hline \multicolumn{2}{|l|}{$\begin{array}{l}\text { Starch } \\
\text { hydrolysis }\end{array}$} & - & + & - & + & + & - & + & - & - & - \\
\hline \multicolumn{2}{|c|}{ Methyl red test } & - & - & - & - & + & - & + & - & - & + \\
\hline \multicolumn{2}{|c|}{$\begin{array}{l}\text { Vogues- } \\
\text { Prausker's test }\end{array}$} & - & - & - & - & - & - & - & - & - & + \\
\hline \multicolumn{2}{|c|}{$\begin{array}{l}\text { Sulphate } \\
\text { production } \\
(\mathrm{mM})\end{array}$} & 0.643 & 0.626 & 0.953 & 0.441 & 1.264 & 0.854 & 1.103 & 0.972 & 0.575 & 0.390 \\
\hline
\end{tabular}


Fig.1 Reduction of $\mathrm{pH}$ in growth media by SOB

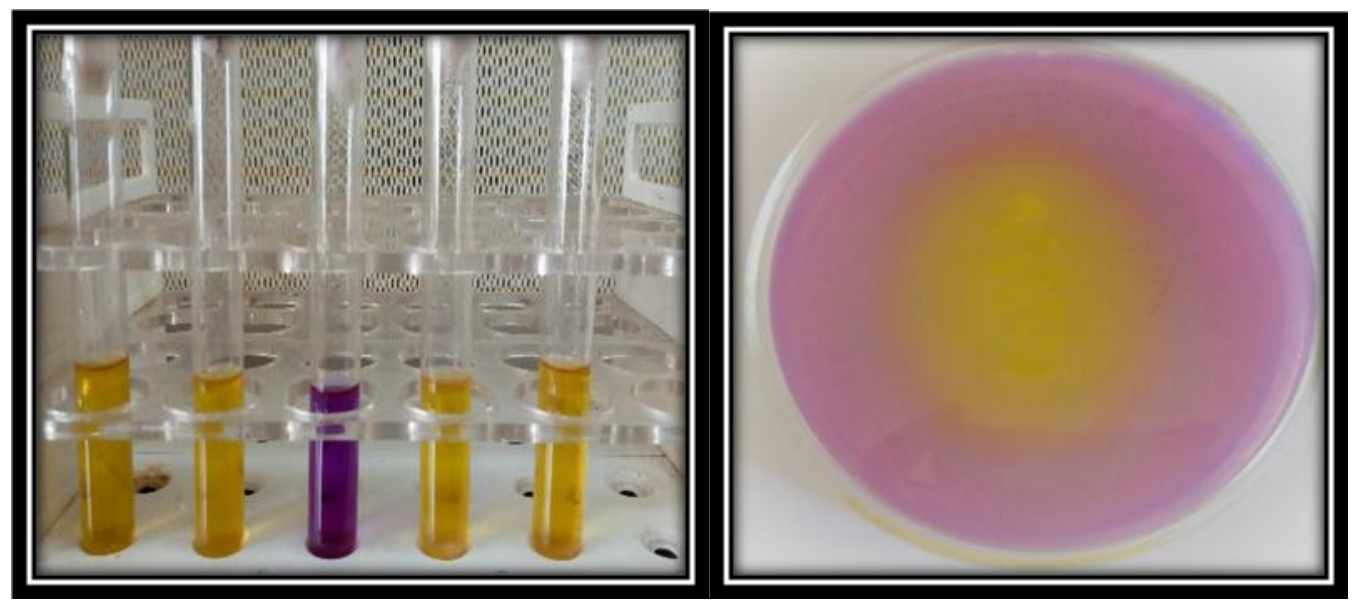

Thiosulphate brothThiosulphate agar (isolate NJS2)

The isolates were morphologically and physiologically best described as Pseudomonas, Stenotrophomonas, Alcaligenes, Bordetella spp and Thiobacillus spp.Sulfur oxidizing Pseudomonas spp. have also been isolated from soils of Bhitarakanika, Odisha, India (Thatoi et al., 2012) and mangrove soils of Mahanadi River Delta (Behera et al., 2014) that produce sulfate ion. In the present investigation, 10 isolates were obtained from rhizosphere soil samples of groundnut and among them five isolates showed good reduction of $\mathrm{pH}$ in growth media (initial 8.0, final below 5.0 in 7 days). The $\mathrm{pH}$ reduction is due to production of sulphuric acid by the oxidation of elemental sulphur by the sulphur oxidizers (Anandham et al., 2005). And sulphate production is highest in the isolate NJS21.264 mM and further the isolates were characterized as rodshaped; all the isolates were Gram negative. The colonies of isolates were circular or irregular in shape.

In conclusion, the sulphate production property of these isolates from rhizosphere soils of groundnut can be used for developing inoculants for oil seed crops and pulses needing more sulphate for improving their productivity and quality.

\section{References}

Anandham, R., Sridar, R., Nalayini, P., Poonguzhali, S., Madhaiyan, $M$ and Tongmin, S. A. 2006. Potential for plant growth promotion in groundnut (Arachis hypogaea L.) Cv. ALR-2 by coinoculation of sulphur oxidizing bacteria and Rhizobium. Microbiological Research. 162: 139153.

Avelizapa, N.G.R., Ramírez, M.G., Gama, R.H., Aburto, J. and Leon, R.G.D. 2013. Isolation and selection of sulphur-oxidizing bacteria for the treatment of Sulphur containing hazardous wastes. Chemical and Biochemical Engineering. 27 (1): 109117.

Behera, B.C., M. Patra, S.K. Dutta and H.N. Thatoi. 2014. Isolation and characterization of sulphur oxidising bacteria from Mangrove soil of Mahanadi river delta and their sulphur oxidising ability. Application of Environmental Microbiology. 2: 1-5.

Beolchini, F., Viviana, F., Sevda, O and Antonio, D. 2017. Sulphur-oxidising bacteria isolated from deep caves improve the removal of arsenic from 
contaminated harbour sediments. Chemistry and Ecology. Http://dx.doi.org/10.1080/02757540.2 017.1281252 .

Cha, J.M., Cha, W.S. and Lee, J.H. 1999. Removal of organo-sulphur odour compounds by Thiobacillus novellus SRM, sulphur-oxidizing bacteria. Process Biochemistry. 34: 659-665.

Hassanshahian, M and Somayeh, G. 2017. Isolstion and characterization of iron and sulphur oxidizing bacteria from Maiduk copper mine at Shahrbabk province in Iran. Geomicrobiology Journal. 35 (4): 261-265.

Hui, Y.Z., Stoven, K., Haneklaus, S., Singh, B.R. and Schnug, E. 2010. Elemental sulphur oxidation by Thiobacillus $s p$. and aerobic heterotrophic sulphuroxidizing bacteria. Soil Science Society of China. 20: 71-77.

Rameshkumar, P., Pothana, S., Manivannan, G. and Manikandan, S. 2014.
Microbiological and molecular characterization of sulphur oxidizing Pseudomonas sp. PRK786 isolated from cattle manure compost. International Journal of Advanced Research 2 (3): 714-722.

Thatoi, H.N., B.C. Behera, T.K. Dangar and R.R. Mishra. 2012. Microbial biodiversity in mangrove soil of Bhitarakanika, Odisha, India. International Journal of Environmental Biology. 2: 50-58.

Ullah, I., Jilani, G., Khan, K.S., Akhtar, M.S. and Rasheed, M. 2014. Sulphur oxidizing bacteria from sulphur rich ecologies exhibit high capability of phosphorous solubilization. International Journal of Agriculture and Biology. 16 (3): 550-556.

Vidyalakshmi, R and Sridar, R. 2007. Isolation and characterization of sulphur oxidizing bacteria. Journal of Culture Collection. 5: 73-77.

\section{How to cite this article:}

Narendra Reddy, A., A. Vijaya Gopal, R. Lakshmipathy and Padma, V. 2018. Isolation, Characterization and Screening of Sulphur Oxidizing Bacteria from Rhizosphere Soils of Groundnut. Int.J.Curr.Microbiol.App.Sci. 7(08): 2639-2644. doi: https://doi.org/10.20546/ijcmas.2018.708.272 